\title{
Former and present attractiveness of industrial sectors in the development process of Poland and Mazovia
}

\section{Andrzej Karpiński}

\section{ABSTRACT}

In the current discussions on the past and future prospects of industry in Poland, at least four areas require, in my opinion, much more attention and reflection. This means learning from our - not always positive - experiences.

Four matters are the most pressing, and I believe that getting answers to the following four questions is of the utmost urgency:

1) What measures to stimulate development, what we sometimes call the "anatomy of growth or development", were applied to the industry in Poland in the initial period of its transformation and during the first 25 years - 1990-2014. Among others, what factors initiated the development, propelled it and contributed conclusively to its further growth, and whether and what changes are currently required?

2) If the state decides to support the development of selected branches and areas of industry that offer the greatest development opportunities - what should be the criteria for their selection and whether they require addenda or corrections?

3) What changes were made in these industries which were recognized as having the greatest development opportunities in the initial period of the abovementioned Polish transformation? What conclusions should be drawn from the changes currently taking place in them?

4) Which branches of industry are and may be the most attractive for development in Warsaw and Mazovia region?

In each of these four areas, there have recently been many new addenda to the existing diagnoses and proposals which seem to be worthy of discussion.

Key words: industry, development, transformation process in industry, attractive industries for Warsaw and the Mazovia region

\section{Anatomy of development in the $\mathbf{2 5}$ years of the transformation}

The need and necessity to interrupt the processes of the deindustrialisation of the country, which dominated in the first phase of the transformation in Poland, and then to enter on the path of modern reindustrialisation, have never been so strong and perceptible as today. This is determined by the new long-term strategy of development adopted today by the European 
Union. It is based on the assumption that "the development of the industry is an opportunity for Europe". This is a complete change in attitude towards the industry. Previously, the notion was that the industry was becoming an increasingly declining sector in a modern economy and would lose its importance in favour of services. The 2008 global crisis, the largest in the post-World War II period, was an important reason for this change. At the same time, due to the current environmental threats in the world, we need to develop only those areas of industry which expansion does not have a negative and harmful impact on the state of nature, environment and climate. In the face of current threats in the world economy this development must and should be much more selective than before and cannot be left only to natural processes.

In this new situation, a broader and much more in-depth analysis is required that will show the mechanisms used for the development of industry during the political transformation after 1989. It was the anatomy of this development as mentioned above. Sometimes it is also called "the anatomy of success". In my opinion, however, in this particular case, it would be a little too much of an overstatement in the light of what will be discussed further on.

In discussions on this subject, one question most frequently arose: "How was it possible that the total volume of industrial production in Poland after 25 years from the beginning of the transformation process, i.e. in 2014, could reach the size of 2.6 times greater than in the last year of the People's Republic of Poland [Polska Ludowa], despite the liquidation of about 1/3 of the industrial potential existing in 1988 after 1989?"

The main factor which made this possible was the introduction of two new drivers of this development in that period. For doctrinal reasons, they could not have been used by the People's Republic of Poland.

a) acquisition by foreign capital some of the former state enterprises by participation in their privatization. This was commonly (although not always) accompanied by a major extension of the scope of their activity as comparing to when they were operating in the People's Republic of Poland. In many cases it meant a transition from expansion only or mainly on the domestic market to expansion on the world market,

b) undertaking new investments in the private industry. Although they involved mainly small and the smallest enterprises (the so-called "micro", i.e. employing up to 10 people), it was implemented on such a large scale that it resulted in a noticeable and significant increase in production.

Both these new driving factors did more than fill the gap caused by the liquidation of $1 / 3$ of the state production assets (considering the employment rate, i.e. the number of jobs and the volume of production, this loss was even greater).

We now have a much better understanding of the impact of each of these factors on the growth of production of the entire industry in this period. It was necessary as it was during these years that the share of enterprises owned by foreigners grew significantly. Their share in the total industrial production of Poland increased from $0.4 \%$ in 1989 (mainly Polish companies) to over $38 \%$ in 2016 . This meant the emergence of a new industry of a completely changed nature.

The share of foreign companies in the growth of production as comparing to its initial level in the last year of the People's Republic of Poland was even greater. It can be estimated 
that the increase in production of foreign-owned companies constituted about $2 / 3$ of the total increase in industrial production reached in that period. Therefore, their role was decisive.

If it were not for this - the growth of production in the industry, owned by the national capital (public and private together) would not exceed $70-80 \%$ in these 25 years, that is by $1.8 \%$ annually. For such a long period, 25 years, it would be a relatively slow growth. In a country, as delayed in industrial development as Poland was, it would mean almost stagnation. Although this increase was much higher in the private industry itself, it had to fill the gap left by the fall in production following the liquidation of a significant part of the state industry.

If such a vast liquidation of the existing plants, which was much larger than in other countries undergoing the transformation (with the exception of the former German Democratic Republic, or GDR in short, where stopping production at a single plant did not always mean its liquidation on a national scale but only its relocation from eastern to western Germany), could have been avoided, then the increase in production in our country would have been much greater. It could have had increased by 3.5 times in our country, instead of by 2.6 times in this period. This would have had a very positive impact on the level of state budget revenues and its financial stability, as well as on the situation on the labour market. Due to our exceptionally high level of unemployment in the 1990s, which reached a massive scale in that period, this could have been of great importance.

At the same time, one cannot fail to notice that the increase in production achieved by us in that period was based to a very large extent on replacing the final production (i.e. covering the entire cycle, from raw material to finished product ready for direct consumption) with the assembly of finished products using only imported elements. This is much easier than the development of final production. It allows avoiding the whole phase of designing and implementing new products to production. Decreasing the share of final production in total production meant going back to the lower phase of the entire production cycle, which Prof. K. Marczewski called the "structural backwardness". ${ }^{1}$ This resulted in a deep regression in the level of industrialization of the country.

The discussion on this subject led to the discovery of a phenomenon which in our country became known as the "Polish industrial paradox". It results from the fact that Poland, in terms of the average annual production growth rate ("Average Annual Growth Rate" or AAGR for short) was on one of the five first places among the European Union countries. At the same time, in terms of innovation and the pace of modernisation of its industrial structure, which will be decisive for the fate of the industry in our country, it was on one of the last 5 places out of $28 \mathrm{EU}$ countries. Such a fundamental discrepancy, therefore, shows all the features of the paradox. That should give a lot to think about. Taking this problem into consideration is, therefore, undoubtedly a new element when evaluating the results of these 25 years.

It is also not difficult to see that the reserves acquired in this way, i.e. through the privatisation of state companies and the establishment of new private enterprises, will gradually

${ }^{1}$ Gospodarka polska 1990-1992, edited by L. Zienkowski, Zakład Badań Statystycznych GUS i PAN, Warszawa 1992, p. 120. 
deplete. In this situation, it is necessary to create new driving factors that could stimulate the development process in the future.

The innovation and creation of a new industry are of the utmost importance. It should base its competitiveness towards other market partners on the innovation of its production and not, as it's been until now, on cheap labour. Industries in which innovation processes are of decisive importance, i.e. high-tech industries, will play a key role in this industry of the future. Therefore, it is not possible to assess the industry's results solely based on the production average annual growth rate of GDP. The use of this indicator in our propaganda has been a great mistake of all the successive governments in Poland.

The much more important indicator, which will be commonly used in the future, is the role of innovative products in the whole industrial production of a country and the share of industries in which innovative processes are becoming decisive for development. These certainly include the electronics and pharmaceutical industries. However, world statistics are only taking the first steps in the methods of constructing these indicators and evaluating their effects. Progress in this area will be of the utmost importance.

\section{Criteria for selection of industrial sectors that offer the greatest development opportunities}

The second area, requiring a broader and more in-depth analysis and better dissemination of knowledge, especially among politicians, are the criteria which should guide the state if it decides to support the development of certain prospective industries. To make their selection an identification of the impact of the development of particular industries on the development of the whole industry is required. It means treating them as components of the system. This, in turn, is a typical macro approach, and not micro one, i.e. from the point of view of individual companies or business sectors of an industry. Since Roosevelt's "New Deal", Silicon Valley in the USA and the implementation of Keynesian theory in Europe in the 1930s, there has been no doubt that the state can actively and effectively influence real development processes in industry and economy also when existing within the market economy. This influence may be both positive and negative.

The main potential positive effect is the possibility of accelerating the development of the whole industry and economy in this way. Its basic condition relies on the ability of accurately identifying and selecting those sectors of industry or areas of its production which are capable of developing the whole industry most dynamically. State actions towards such solutions are sometimes referred to as "picking winners and losers". This practice is heavily criticised by orthodox economic neoliberals. If these industries are correctly identified, the results are great. This makes them be widely used even in countries with extremely neoliberal doctrines, such as the USA. That is why in the 20th century, especially since J. Schumpeter, the problem of criteria for this choice became the centre of discussion among economists and industrialists. 
In countries existing within market economy, these criteria were most often seen in 3 typical market indicators, such as:

(a) an industry's highest profitability or best return on capital invested, i.e. profitability,

(b) a strong competitive position in sales on the market,

(c) an opportunity to exploit market gaps and niches.

The weakness of these criteria is the fact that changes, sometimes even very profound ones, can occur very quickly. Hence, they fail as criteria for more long-term choices. On the other hand, industrialists and businessmen know exactly where the greatest profits can be achieved and have a better understanding of these opportunities than scientists or state administration workers. Therefore, it does not seem advisable to replace them in their functions.

British economist Arthur Pigou introduced a new concept at the turn of the 19th and 20th centuries, which was called "externalities". ${ }^{2}$ It is understood as the effect of using manufactured products of a given sector of industry or technology by its users, i.e. by entities outside the unit that produced them. Hence, A. Pigou is considered to be the creator of the application of this category in economics.

A clear distinction is made between positive and negative externalities when referred to the whole industry and to certain sectors. The latter, i.e. negative externalities, most often concern social and environmental effects. Their recognition and even more so their prevention goes far beyond the capabilities of industrial corporations or businesses. This external effect is usually measured by the scope of dissemination of new technologies and more efficient economic and technical solutions among the users. This is rarely reflected in the profit and financial indicators of the producer. Therefore, the influence of particular sectors on the overall economic result of the whole industry is additionally taken into account. It is measured by the improvement of macro-economic indicators such as: capital intensity, material intensity, energy intensity, labour intensity, import-intensiveness per unit of production value.

This problem has also been addressed in our country. In 1982, in the People's Republic of Poland, the Interdepartmental Governmental Team was established to rebuild and modernize the structures of the domestic industry. The said group proposed very innovative solutions for those times. They can be summarised in 3 basic points:

a) The "external effect", the category of "externalities", was indicated as a criterion in our country. At that time, it was much different from the trends prevailing in other countries, and only later did it gain wider support in them. We can, therefore, say that in this respect we were ahead of other countries, at least within the framework of the Council for Mutual Economic Assistance (in short, the COMECON),

b) The second proposal was even more radical. It was recognised that possible sectoral priorities and resulting privileges for selected industries should be applied only and exclusively to those, which products used by their users produce significant "externalities" on a large scale. They were sometimes called "industries of high

\footnotetext{
2 „The Economist" dated 19 August 2017, p. 54.
} 
chance" in our country. They most frequently occur in industries spreading modern technologies in an economy, which bring about changes in quality, and hence they are called "break-through- technologies". Such technologies, especially in their early development, generally require protection on the market.

What was even more radical, it was determined that the application of these sectoral priorities made economic sense only if the external effects caused by the application of sectoral priorities significantly exceed the expenses of the state or local government necessary to launch their promotion. Consistent adherence to this principle would even mean abandoning the application of priorities even in the case of those industries and areas which are of great social and economic importance in a given economy. It is because their development does not generate any external effects.

c) A third element was the proposal of creation of metrics that were to be used to measure these externalities. This in turn allowed to determine the size of external effects caused by the development of particular industries and production areas. Assessing which of these externalities are the biggest and most stimulating for the development of the entire industry and economy is even more important. This allowed for identifying which industries, within our specific natural conditions and with their favourable development, achievements and past traditions, may play a special role in our industrial development. They should ensure our competitiveness to other market partners, and thus become our national speciality ("National or Local Championship"). This creates conditions for identifying possible directions of specialisation of a given industry in terms of competition in foreign markets ("National or Local Champions"). On this basis, a specialisation programme and its main directions should be developed.

This team expressed its support for the specialisation of following 7 industries in Poland.

These were: pharmaceutical, cosmetic, rolling stock and means of public transport, shipbuilding, equipment for power plants, pulp and paper and arms industries. Except for the shipbuilding industry, all these industries were later listed as having a high chance in research, which will be discussed in the next chapter.

These proposals caused deep controversy. They threatened the preferred traditional branches of industry (coal mining, metallurgy and mechanical engineering). Thus, they faced heavy opposition from the combined heavy industry, which played a key role in our industry at that time. It was strongly represented in political authorities (Silesia and the Coast) and as a result, these proposals were rejected in their entirety.

This initiative was taken up again only after the political change in 1989, at the beginning of the transformation process in 1995. It was put forward by the Polish Economic Society (PTE), and not by the government and the state. At that time, however, the doctrine of economic neoliberalism in its most extreme version was already dominant in our country. Strict following of the doctrine in Poland was much more common than in other countries of political transformation. That is why Prof. G. Kolodko accurately called it "Vistula 
neoliberalism “3 as it is characterised by a number of negative features. The government of that time once again completely rejected this concept. Even though the proposed criteria could have been very useful for industrial practice. They would provide decision-makers, both at the central and regional level, with clear scientific criteria to assess the demands of individual industries and to ensure that they have the highest priority in accessing investment resources. At the same time, they would enable opposing political pressures, which were common before 1989. On the other hand, it would limit the choice by immediately eliminating the industries not meeting these criteria. Unfortunately, this opportunity was not seized.

\section{The fate of industries recognised in 1995 as areas of high opportunity after 20 years of the transformation}

The third area which, in my opinion, requires much more attention and in-depth, critical analysis, both at the level of the entire industry and in each region, as well as in cities with more serious industrial potential, is the study of changes in the industries considered to be "high opportunity" at the start of the transformation.

In this light, it should be recalled that in 1995 the necessity arose to choose a path for further development. It was after the return to the previous levels of production after the decrease in production by $24 \%$ in the years $1990-1994$ was levelled out.

Following the criteria outlined in chapter 2 . of this study, an attempt was made to identify the areas of industry which offer the greatest chance for development in our country. The sectors of industry which, as a result of these analyses, were ranked at the top 15 are presented in Table 1.

\footnotetext{
3 „Przegląd" dated 19 October 2015, p. 9.
} 
Table 1. The most attractive industrial sectors for the development in Poland in research of 1995

\begin{tabular}{|c|c|c|c|c|c|c|}
\hline \multirow{2}{*}{$\begin{array}{l}\text { Ranking } \\
\text { position }\end{array}$} & \multirow{2}{*}{$\begin{array}{l}\text { Symbol } \\
\text { according } \\
\text { to PKD } \\
2004\end{array}$} & \multirow{2}{*}{$\begin{array}{l}\text { Name of the industry } \\
\text { sector }\end{array}$} & \multirow{2}{*}{$\begin{array}{c}\text { Overall } \\
\text { scores in } \\
1995 \text { in terms } \\
\text { of the } 14 \\
\text { macro- } \\
\text { economic } \\
\text { criteria - in } \\
\text { points }{ }^{\text {a) }}\end{array}$} & \multirow{2}{*}{$\begin{array}{c}\text { Externalities } \\
\text { adjustment } \\
\text { factor }^{\text {b) }}\end{array}$} & \multicolumn{2}{|c|}{$\begin{array}{c}\text { Share of total industrial } \\
\text { production in } \%\end{array}$} \\
\hline & & & & & $1989 \mathrm{r}$. & $1995 \mathrm{r}$. \\
\hline 1 & 2 & 3 & 4 & 5 & 6 & 7 \\
\hline $\mathrm{x}$ & $\mathrm{C}+\mathrm{D}+\mathrm{E}$ & TOTAL INDUSTRY & $\mathrm{x}$ & $x$ & 100.0 & 100.0 \\
\hline & & $\begin{array}{l}\text { including: } \\
15 \text { high opportunity } \\
\text { industries listed together } \\
\text { below }\end{array}$ & $\mathrm{x}$ & & 8.5 & 9.4 \\
\hline 1. & 35.3 & $\begin{array}{l}\text { of which: } \\
\text { - aviation }\end{array}$ & 254 & 0.70 & 0.4 & 0.3 \\
\hline 2. & 31.5 & - lighting equipment & 250 & 0.80 & 0.6 & 0.3 \\
\hline 3. & 24.4 & - pharmaceutical & 248 & 0.65 & 0.8 & 1.1 \\
\hline 4. & 33.1 & - medical devices & 244 & 0.90 & 0.1 & 0.1 \\
\hline 5. & 31.2 & $\begin{array}{l}\text { - switchgear } \\
\text { and security devices }\end{array}$ & 239 & 0.80 & 0.3 & 0.4 \\
\hline 6. & 29.11 & $\begin{array}{l}\text { - turbines and power } \\
\text { plant equipment }\end{array}$ & 237 & 0.85 & 0.2 & 0.5 \\
\hline 7. & 32.2 & $\begin{array}{l}\text { - telecommunications } \\
\text { equipment }\end{array}$ & 230 & 0.95 & 0.3 & 0.3 \\
\hline 8. & 33.2 & - measuring equipment & 228 & 0.90 & 0.4 & 0.3 \\
\hline 9. & 30.02 & - computer & 228 & 1.00 & 0.01 & 0.02 \\
\hline 10. & 33.4 & $\begin{array}{l}\text { - photographic and } \\
\text { optical equipment }\end{array}$ & 228 & 0.90 & 0.1 & 0.0 \\
\hline 11. & 32.1 & - professional electronics & 221 & 0.95 & 1.1 & 1.0 \\
\hline 12. & 25.2 & $\begin{array}{l}\text { - cosmetic and hygiene } \\
\text { products }\end{array}$ & 219 & 0.65 & 0.7 & 0.4 \\
\hline 13. & 22.1 & - pulp and paper & 206 & 0.40 & 1.0 & 1.3 \\
\hline 14. & 24.3 & - paints and varnishes & 206 & 0.65 & 0.5 & 0.4 \\
\hline 15. & 34.1 & - automotive & 205 & 0.70 & 2.0 & 3.0 \\
\hline
\end{tabular}

a) Methodological assumptions and results for all industries are presented in the paper: A. Karpiński, Prawda i klamstwa o przemyśle, published by the Oratio Recta Foundation, Warsaw 2018, pp. $289-291$.

b) The score for the macroeconomic assessment (column 4) was adjusted by the indicator of the amount of 'externalities'. They are caused by the development of a given industry, where 1 is considered as the highest value based on the development of the computer industry. 


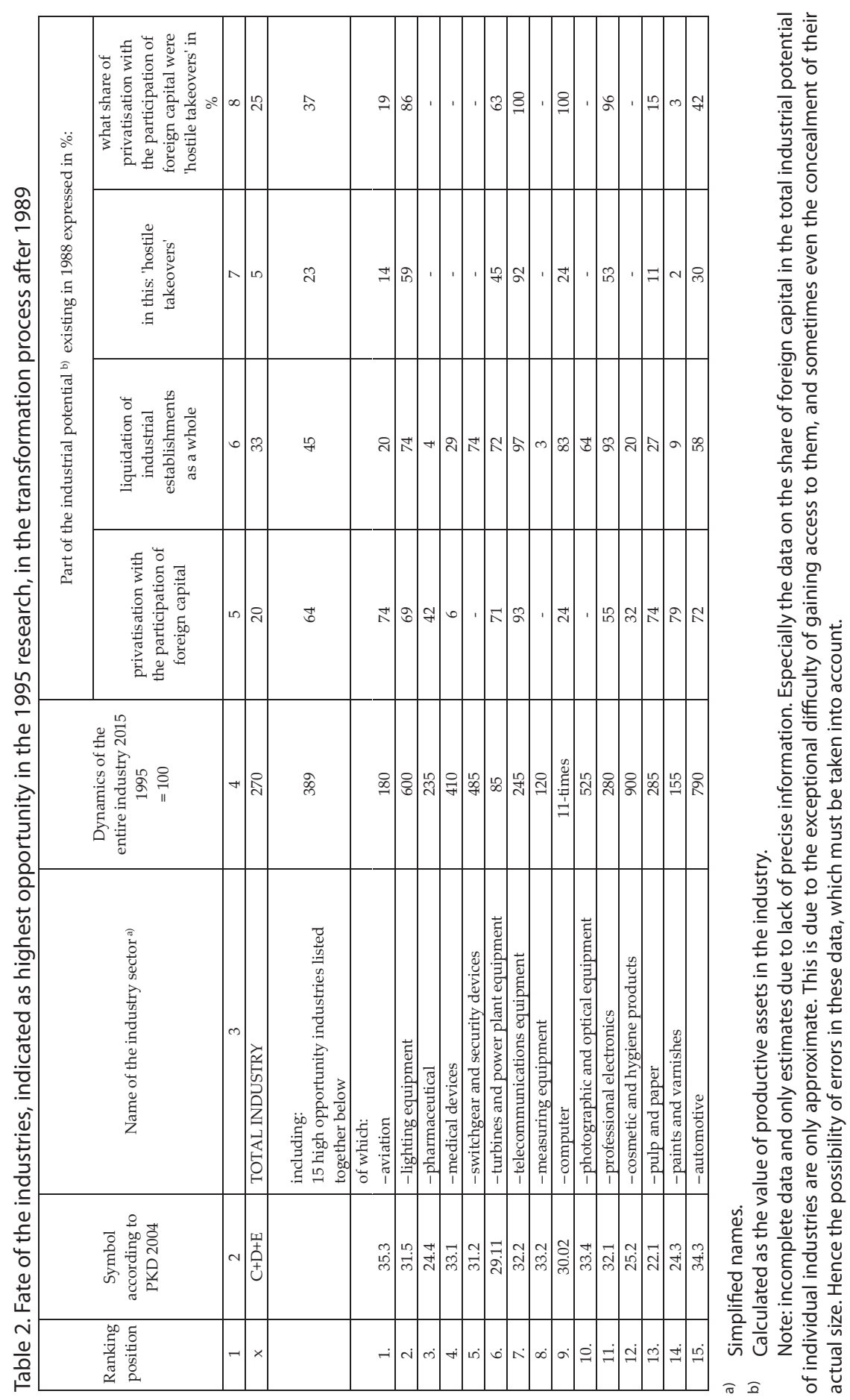


The higher the overall score of particular industries, with the average score for the entire industry being 100, the more the development of a given industry contributes to the improvement of macroeconomic and efficiency results of the whole industry.

The correction factor in column 5 of Table 1 identifies the extent of externalities caused by the development of a given industry. These estimates only covered one level of industrial sectors, i.e. industries marked with two-digit symbols in the Polish industrial classification [PKD]. A lower-level analysis would give better results. Thus, these estimates are only approximate and indicative so far.

The identification of these industries allowed for an even more important question to be asked and for an attempt to answer it, namely: "What was the fate of industries of the highest opportunity," according to a study of 1995, during the following 20 years of industrial transformation in Poland? The answer to this question is provided in Table 2.

Table 2 specifies at least 3 basic statements:

a) The 20 years of transformation confirmed that the industries initially included in the group can make the development of the industry as a whole more dynamic. While all industrial production of these 20 years (1996-2015) increased by 2.7-fold, the „industries of the highest opportunity" recorded a 3.8-fold increase. It was 1.5 faster than the whole industry. If small plants operating in these industries were to be included (employing up to 49 people), the total increase in their production would be 4 times bigger. In this group, sectors of the industry with a faster development dynamic than of total industry were dominant. In as many as 9 out of 15 included in this group, i.e. in $2 / 3$ of them, the production growth dynamics exceeded that of the whole industrial production. The following areas of industry were developing the fastest, positioned by a ranking method: computer industry (11-fold growth despite the liquidation of the largest factories in this industry), cosmetics (9-fold), automotive (including the production of spare parts - 8-fold), lighting equipment (6-fold), photographic and optical equipment (mainly laser instruments - 5-fold), electrical switchgear (almost 5-fold), medical equipment (4-fold), pulp and paper (almost 3-fold) and professional electronics (also almost 3-fold).

This increase would have been even higher if it had not been for the fact that a number of industries in this group were developing their production in our country at a slower rate than the whole industry. In other countries, during the same period, their growth exceeded the growth of the whole industrial production. The following industries are included in this group: pharmaceutical (2.3-fold growth), aviation (1.8-fold growth), paints and varnishes (1.5-fold growth) and measuring equipment (1.2-fold growth).

Our slower growth of production in these industries was mainly due to 2 reasons, namely:

- the liquidation of main plants in 2 sectors (mechanical engineering for power plants and apparatus industry),

- the growth of import of products manufactured in these industries was much faster than their domestic production. This concerned 5 out of the 15 industries 
mentioned above, namely: aviation, pharmaceuticals, measuring equipment, paints and varnishes and computer equipment, which was justified in this case. Distinguishably for these industries, the import of their products increased 3 times faster than their production in the country. As a result, the sales of their products on the internal market (including import) increased much faster than the sales of all industrial products in our country. Only exporters of these products to our market benefited from it, not their domestic producers.

The slower growth of production in these industries than in total cannot be explained by any objective reasons. This was therefore not unavoidable and was caused by the unfavourable results of the market game. It meant that the existing opportunities in these areas were not taken.

The actual results, therefore, confirmed that also these industries can make the whole industry and economy more dynamic.

It also indicates that choosing these 15 industrial sectors and including them in the group of the highest opportunity in 1995 was accurate.

Two out of fifteen industrial sectors included in this group noted a decrease or stagnation in their production rate when comparing to its level in the People's Republicof Poland. This concerned the power plant equipment industry (which was caused not only by the liquidation of the turbine factory in Elblacg but also of the factory of electric motors and high power transformers in Wrocław and Łódź). The second was the measuring equipment industry in which numerous small plants were established as a result of decentralization. This increased overall production, but the main large plants were liquidated. Had it not been for this, the expansion of all these 15 industry sectors would have made the development of industry and theeconomy most dynamic.

b) The second feature of these 15 most attractive for development industry sectors, was a much faster expansion of foreign capital than in the industry in general. The exceptionally high share of foreign capital in the privatisation of these state-owned companies indicates that. Foreign capital took part in the privatisation of about $20 \%$ of the total industrial potential existing in 1988. Whereas in these 15 sectors this share was as high as $64 \%$, it was then over 3 times higher than in the whole industry. This clearly shows that the expansion of foreign capital was exceptionally active in these industries.

Thus, wecanspeakofanextraordinary concentration offoreigncompanies' expansion on these industries and their particular interest in them. As a result of the privatisation, foreign capital took over $50 \%$ of the entire industrial potential of these 15 sectors existing in 1988. It is worth noting, as the foreign literature indicates, that when the share of foreign capital exceeds $40 \%$ of the entire potential of a given industry, a threat of losing direct control over it occurs for a country. It influences the processes and the development decisions made in such an industry. Hence, this share is considered to be an upper limit, the crossing of which poses certain dangers.

The highest share of foreign capital participated in the privatisation of the assets of the following industrial sectors, ranked successively: the telecommunications 
equipment industry (about 93\%), paints and varnishes (79\%), aviation (74\%), pulp and paper $(74 \%)$, automotive $(72 \%)$, turbines and equipment for power plants (71\%), lighting equipment (69\%), professional electronics (55\%).

Such a high activity of foreign companies in these industries indicates that the situation in our country was well understood by them. Such research was not conducted by our industrial administration. Paralyzed by neoliberal doctrine, it did not provide domestic companies with adequate protection against unfair competition or sufficient support in their development.

c) The third feature of transformations in these industries, but unfavourable to us, was the extremely large share of so-called "hostile takeovers". It meant purchasing companies not to further develop their production but to close them down and thus control the local market for own products. This also eliminated competition in the local and foreign markets. The extent of these "hostile takeovers" in the whole industry in Poland was almost two times higher than in Western Europe $23 \%$ in Poland compared to $10-15 \%$ on average in EU countries).

In some of the industries analysed here, the share of "hostile takeovers" was exceptionally high and reached levels not observed in other, even some western neoliberal-oriented, countries. It was the highest in the following sectors: telecommunications equipment industry, computer industry, turbines and power plant equipment, automotive industry (in contrast to the Czech Republic and Romania, the existing domestic brand of cars was not preserved).

It is noteworthy that three out of four of the above-mentioned sectors belong to "high technology industries." They are of key importance to the modernization of industrial companies of almost all sectors. At the same time, they are a part of the electronics industry, in which the losses in its potential existing before 1989 were the highest in our country.

Allowing this to happen is a serious mistake of our industrial administration. It cannot be explained even by strict, near to doctrinal, following the principles of neoliberalism. Some other countries undergoing the transformation, such as the Czech Republic and Hungary, were able to avoid this to happen.

To sum up, the above analysis allows for an attempt to generalise and to assess the positive and negative aspects of these changes. Of the 15 industries covered by this analysis:

- 7 were taken over by foreign capital,

- 4 were liquidated (as the loss of potential existing in them before 1989 exceeded 75\%, and then we can speak of actual liquidation),

- only 4 retained the domination of domestic capital, but it was enough to stimulate their development.

Of the fifteen sectors analysed above, the main plants in these sectors were usually closed. An example can be found in the professional electronics industry - plants in Piaseczno and Warsaw; in the telecommunications equipment industry - three plants being some of the largest in Europe, namely in Radom, Bydgoszcz and Warsaw; in the equipment for power 
plants industry - in Elbląg, Łódź and Wrocław; in the computer industry - in Wrocław and Błonie; and in the lighting equipment industry - in Piła and Warsaw.

They were often replaced by numerous small private companies and the individual production activities operated by the former employees of the liquidated companies. It was accompanied by the emergence of various forms of the "cottage industry". This assessment cannot be altered by the fact that some of the previously existing industrial potential is still remaining.

Their position on the market is much weaker than that of large companies. They are less resistant to changes in the economic situation and they are less oriented on export. Above all, they do not play a major role due to the weakness of their R\&D in terms of innovation and modernization of industrial structures. The ability to innovate will decide about the future in Poland.

This resulted in the creation of an unfavourable arrangement in Poland, which does not support innovation processes in the industry and economy. It is reflected by a lower than in other countries share of innovative industries, especially 'high-tech industries', in the total industrial production. This results in underdevelopment of our electronics, computer, precision, biotechnology and especially chemistry industries.

How should these changes be evaluated? The sole purpose of increasing the share of foreign capital in the industry in Poland was right and was in line with the assumption adopted at the beginning of the transformation. It was a condition for the creation of a market economy in Poland. It would not have been possible without opening our economy to the global market and foreign competition. At the same time, it created an opportunity for transition to a modern model of development. It is characterised by opening the domestic industries to foreign investments. At the same time, it is indisputable that:

- the extent to which the foreign capital would take over these industries turned out to be much greater than expected and predicted at the beginning of the transformation. It surprised the decision-makers and authors of this concept,

- the share of foreign capital in the industry in Poland is currently one of the highest in Europe, with the exception of small countries such as Lithuania, Latvia and Estonia,

- this share is already very close to the $40 \%$ limit, i.e. the aforementioned level, the exceeding of which poses a direct threat of losing the state's influence on the development processes in these sectors,

- as a consequence, the sectors controlled by foreign companies, in comparison to domestic plants, experienced a qualitative increase in the prices of their products. This meant an increase in expenditure on the purchase of these products in the state budget and families budgets. It burdened the whole society (e.g. medicines).

Such radical changes in this period allowed for achieving unimaginable technological breakthroughs in a number of sectors of industry and economy. This, in turn, resulted in a breakthrough in the civilisation level of our society (computerisation, telecommunica-tions, automotive, etc.). Therefore, a number of unfavourable phenomenon and failures to some extent can be regarded as the price of progress and undeniable achievements in this period

How to evaluate the future prospects of these industries? The liquidation of particular plants usually resulted in far-reaching destruction of the entire sector's industrial potential. 
It affected the existing cooperation and production structures, caused an outflow of managerial staff, often out of the country, with a little chance for their return. The Polish electronics industry workers are a good example. They created the electronics industry in Norway from scratch. Therefore, the reintroduction of domestic capital in these industries seems unlikely nowadays, if not impossible.

Under these conditions, our main focus must now be set on new areas and industries where we can compete effectively. Such a process is already taking place on a large scale due to the relatively high activeness and entrepreneurship-oriented approach of the Polish businesses. Future sectors of high opportunity will certainly differ significantly from those assessed as such in the 80 s and 90 s of the last century. But even more so, launching appropriate research to identify them is nowadays the most urgent task.

As a result of the changes presented above, the ownership structure of the industry in Poland changed completely. The industries classified as the fifteen most attractive for the development process became to a large extent "affiliates industries", i.e. in which the decisive role is played not by domestic capital but by subsidiaries of foreign concerns that entered our market.

If the most attractive for development industries were to be strongly protected and the processes of privatization were controlled right at the verge of the transformation, such radical changes would not have to be so profound. It would create a well-thought-out modern sectoral industrial policy that was closely integrated with the policy of ownership transformations. As a result, their directions often diverged. This can be proved by the complete collapse of National Investment Funds in industry. Unless their hidden agenda was to accelerate the liquidation of the state industry.

New elements of the existing diagnoses concentrate mostly on the social aspects of the liquidation of many plants. An attempt is made to answer the question: "What were the social consequences of a liquidation of plants or industries in a specific area?" This is particularly important for regions and industrial cities, which bear the main burden of the transformation. In total, this affected almost 2 million people who lost their jobs in the liquidated plants.

A book by Katarzyna Duda is an example of such an analysis. It is based on the situation in Wałbrzych. ${ }^{4}$ In the discussion on this topic, it was stated that: "The most important change in the lives of many people was the collapse of their factories." ${ }^{5}$ The towns with only one large factory liquidated after 1989, which was the basis for the existence of this local community, experienced the greatest problems. For them, the liquidation meant the disappearance of the only source of income. There were many such places even in Mazovia alone. An increase in the activity of local authorities in this field, although not eliminating these liquidations, may significantly reduce their negative social consequences.

\footnotetext{
${ }^{4} \mathrm{~K}$. Duda, Kiedyś tu było życie - teraz jest tylko bieda, published by Książka i Prasa, Warszawa 2019.

${ }^{5}$ Gdy stracili pracę, skończyło się wszystko, interview with Katarzyna Duda by Jakub Dymka, „Przegląd” dated 24 June 2019, p. 17.
} 


\section{The most attractive industrial sectors for development in Warsaw and Mazovia region}

To choose the "highest opportunity" sectors of industry, one must first answer the question: "Why is it necessary to make such a choice at all and why failing to do so may result in losses and negative social phenomenon?" This concerns every area, both the country as a whole and regions or cities with significant industrial potential.

There are clear analogies and similarities between the fate of specific industrial plants and that of particular people. Industrial plants are established, mature, reach the peak of their production capacity, enter the period of decreasing importance and disappearance, and finally inevitably end their existence. This last stage, therefore, is called "declining industries". This period can and must be foreseen in advance. A good host in every province, region or industrial city has to answer the question: "Which industries with traditions in the territory can I close in the next 10-15 years and whether there are new ones that can fill the gap caused by the collapse of traditional industries?" This requires an analysis of the structure of the existing industry in a given area. Unfortunately, this awareness is very limited and insufficient in our country. This requires a look into the future much longer than a 5-year cycle of elections to subsequent assemblies [sejmik] or city councils. The lack of such a longer look is too common in our country. Attitudes of this kind ("shorttermism") are increasingly criticized even in countries with neoliberal orientation. An important reason for this is the false limitation of the attention of local governments mainly to the local government sector in a given area.

For effective management to take place it is necessary to look at the contemporary economy from a longer perspective ("longtermism"). This applies even on the scale of regions and larger cities. Therefore, it is necessary to provide local authorities with a broader view of the entire economy, not only of a local government sector, of a region or a city. This requires a more comprehensive view of the economy, including private, centrally managed entities andx the local government sector. Its lack is often the main weakness and one of the reasons for failures and delays in the modernisation of the industrial structure in particular regions and cities.

Before attempting to identify which industries may have opportunities for development in Mazovia, it is necessary to present additional conditions which should be met by these new plants and industries that will entitle them to the local "authorities" support. At least four of these features should be taken into account, namely:

a) those establishments that are among the areas of interest of the European Union would have the best chance of development. Therefore, they can count on a preferable treatment, namely:

(aa) support from European Union funds,

(ab) gradual easing of the sanctions intended for "public aid",

b) those which may entirely utilize the potential of universities, scientific institutions and $R \& D$ centres located on a given territory,

c) those that meet the requirements of "eco-neutrality", i.e. an increase in emissions fully balances the reduction in existing pollution, 
d) those that have a chance of gaining the widest public support for them from local communities, not only business and local administration but also hobbyists of various types and nongovernmental organisations. Thus stimulating a sense of local business partnership.

These requirements could be fulfilled by the industries that could be the driving factor in the development process in the Mazovian region, namely those that cause:

a) the highest growth in demand for goods and services manufactured in these sectors of industry. It should be at least twice as high as the total growth in demand for industrial goods, which may make the entire industry in a given area more dynamic,

b) maximum use of the scientific and implementation potential existing in Mazovia, particularly strongly developed here in comparison with the country,

c) maximum use of post-industrial areas equipped with industrial infrastructure left after liquidation of plants, which Mazovia has the largest resources in the country,

d) referring to the territory's tradition of development of given industries, related sectors and technologies,

e) entering the cross-border cooperation with countries at an advanced stage of development of these sectors of industry.

In the light of the criteria presented above, the 12 following industries seem to have the greatest chances for the emergence of new branches of industry in Mazovia:

1. The electronic and computer industry. These industries are now entering a period of a massive transition to a new generation of technology and adapting to digital technologies. The use and application of "artificial intelligence" on a mass scale will be a breakthrough. As a result, industrial plants capable of participating in this process will experience an exceptionally high - the highest in the whole industry growth rate of demand for their products until 2035, i.e. over the next 15 years.

The highest increase in demand for these products will occur:

- a new generation of equipment for the Internet and professional electronics,

- electronic equipment for nanotechnology,

- $\quad$ electronic components for industrial and service robots.

Participating in the development of these industries more actively would create a great opportunity for the region.

The development of these industries in Mazovia, in comparison to other regions, is supported by the presence of more favourable development conditions due to:

- the development traditions of these industries in this area,

- exceptionally high volumes of unused post-industrial area, equipped with industrial infrastructure. The scope of plant liquidation in this area was the largest in the country (Tarchomin, Wola, Służewiec, Praga, etc.),

- $\quad$ access to the largest concentration of universities, scientific institutions and R\&D centres in the country.

Except for the Lesser Poland Province (Kraków) and Dolnośląskie Province (Wrocław) Mazovia has the most favourable conditions for the development of these industries. This seems to encourage the reconstruction of the electronics industry in this area, as it suffered 
the greatest losses. Following the example of Ireland, we should skilfully cooperate with global concerns operating in these industries.

2. Green industry. It produces the widest range of equipment, materials used for environmental and climate protection, tools necessary for control and monitoring, and so-called "clean technologies" and reducing environmental risks. It is the industry with the greatest development opportunities. It is now recognised as a major growth sector in the 21st-century industry. Within the next 10 years, the global demand for these products is expected to increase by 1.5-2-fold, i.e. over $10 \%$ annually.

Mazovia has no experience in this industry. It seems that the production of equipment for environmental monitoring, with existing research works, could have the greatest chance in this area. The presence of this sector in the structure of the industry in a given area creates an opportunity to boost the development of the entire industrial production. Therefore, its development in Mazovia deserves special attention and support from local authorities.

These opportunities would increase significantly if the development could be established with the German industry, which is leading in this field.

3. Equipment for renewable energy. The industry is expected to grow by $30 \%$ per year over the next five years and by no less than $20 \%$ per year over the following five years on a world market scale. Such a high rate of growth encourages taking on the risks associated with this industry. Taking the electro-technical traditions of Mazovia into account, it seems that the production of equipment for the energy sector based on the use of solar energy (solar batteries and collectors and photogalvanic devices) would have the greatest chance.

4. Pharmaceutical industry. The industry now needs to switch to the production of nextgeneration products for gene therapy that will reach a massive scale. At the same time, there will be a substantial increase in the production of health prevention and screening solutions. Their share will increase from $1 / 3$ to $40 \%$ of all health care expenditure. The use of biotechnological oncological drugs may offer even greater prospects for development.

The development of this industry in Mazovia is supported by its long traditions there and availability of equipped post-industrial area in Warsaw (Tarchomin and several locations in Wola). Production of generics, i.e. medicines not protected by patents, would have the greatest chance. It is because their production in the country may be much cheaper than import, which would allow us to limit budget expenses of increasing expenditures for this purpose.

5. Special chemicals industry. It produces chemical solutions tailored to the specific needs of individual industries and customers. In the future, thanks to the computerisation of the industry, adapting production to the individual needs of consumers will be much more accessible - it's referred to as "customisation". The demand for these products is exceptionally diversified and different in almost every branch and field. This creates great opportunities for local industry to specialise in the production of a specific type of these solutions. 
6. Biotechnological industry. It is currently experiencing a period of prosperity and bioengineering is now becoming a new sector and type of industry. The prospects related to it could be even bigger if the current predicting of a breakthrough in the use of these forms for oncological therapy turns out to be true. This industry is heavily dependent on R\&D facilities and universities which are present in Mazovia.

7. Optical industry. The largest increase in demand in this area concerns laser devices, which are more frequently used not only in the industry. The development of this industry in Mazovia is supported by existing advanced research on laser technology and the accessibility of post-industrial areas (Warsaw, Praga district and the Optics Centre).

8. Nuclear industry. It produces isotopic preparations increasingly used in medicine, science, industry and environmental protection. They are also increasingly used in medical diagnostics, especially in oncology. The development of this industry in Mazovia, apart from the high dynamics of demand, is supported by the fact that it is almost a monopolist in the country (the centre in Świerk near Warsaw) and we are one of the largest producers in this field in Europe.

9. Electric and hybrid car manufacturing industry. The world now needs to switch to lowcarbon cars and those not emitting dangerous gases generated during the activation of brake shafts. The only alternative to an increase in production of cars with new engines would be to freeze the state of cars completely at the current level and to introduce drastic restrictions in this field. An increase in the production of low-carbon vehicles is inevitable. Warsaw has traditions and large post-industrial areas equipped with industrial infrastructure after the FSO factory in Żeran. However, it is not yet clear whether it would be possible to create a centre capable of designing and producing cars with new propulsion. Even the assembly of these cars alone would be very attractive.

10. Space industry. It is now developing so rapidly that it offers opportunities for medium and small countries to develop the production of rocket equipment and for space exploration. The development of this industry in Mazovia, even without previous traditions, is supported by the fact that this industry is a carrier of the most modern technologies. The lack of which here may affect the technological level of the entire industry in a given region. To launch this industry in Mazovia, close cooperation is required with Wrocław and Białystok, which are the most advanced in the development of this type of production.

11. Medical devices and equipment. The industry is forecasting the largest increase in demand as a result of the digitalisation of health care on a scale never seen before, i.e. the application of digital technology in medicine. It is considered to be one of the most dynamic industries in the 21st century. Demand for these products is expected to grow over the next 20 years. This applies especially to equipment for diagnostics and prevention, where the breakthrough will be the biggest. This will require a huge increase in expenditure on such equipment, which in most countries is financed from state and local government budgets. 
12. Production of products supporting the metropolitan functions of Warsaw as the capital city, especially in information equipment and information agencies.

These 12 industries offer greater than in the rest of the country possibilities of undertaking new innovative production ("start-up").

To sum up, I believe that if the Mazovian authorities choose to support and promote new industries in their area, they should first of all concentrate on these 12 sectors. Aiding newly established companies may give the greatest "externalities" and pro-development effects. Therefore, it has full economic justification.

Apart from these 12 industries, Mazovia seems to also have more favourable conditions than other regions for the development of sectors producing materials and equipment used in modern education. It is due to the mass production of digital manuals, e-books, computer games and equipment for the entertainment industry. The research of such opportunities is not yet completed and the detailed outline of development opportunities for these sectors is not available.

Mazovia has a long tradition in the armaments industry. However, there is a tendency in the world to avoid locating facilities of this industry in capitals of countries and metropolises in order not to pose an additional threat to them. However, even there would also be some opportunities if we could cooperate with e.g. Israel, leading in this field.

One can put forward a notion that an increase in the employment share of these industries in the Mazovia region ${ }^{6}$, which is currently estimated at $8-10 \%$, should reach at least $20 \%$ in the years $2020-2035$ and even $1 / 3$ or $40 \%$ in the long term. Mazovia has the best and most favourable conditions for the development of these industries in the country and this opportunity should be used to the maximum.

The local authorities of Warsaw and the regional government should additionally support the development of these industries, which are the most valuable for future development. Undoubtedly, Warsaw needs greater support from the state and local governments to stimulate the development of most modern industries. They could fill the gap that will arise as traditional industries in this area disappear.

This could be supported by actions such as:

a) creating the local promotion policy for industries most desirable in this area and modernising their structure. This should be implemented by:

- facilitating access to post-industrial areas,

- reduction of taxes and local benefits,

b) creation of a Regional Reindustrialisation Staff, linking representatives of central and local administration with representatives of business, science, NGOs, even hobbyists of various kinds. This would create a climate for a business local partnership,

c) establishing cross-border cooperation with partners more advanced in the development of 'highest opportunity' industries.

\footnotetext{
${ }^{6}$ Trendy zmian w poziomie i strukturze zatrudnienia w województwie mazowieckim w latach 1999-2008, Mazowieckie Biuro Planowania Regionalnego, Warszawa 2012, pp. 79-91.
} 
Summing up, these considerations can be concluded with one basic conclusion. It applies not only to the whole country but also to every region or a city. It can be considered as the main message of this paper.

Most of the weaknesses and irregularities in our economy identified in this study are caused by the short-sightedness in assessing the impact of processes and changes taking place in our economy and the resulting problems. This is due to looking at the it from a short perspective and fully applies also to regions and cities, which play a key role in the development of the economy.

It seems that this phenomenon has occurred with exceptional intensity in our economy and has particularly harmful consequences.

If the reading of this study leads us to pay more attention to these aspects of our development, I will consider its objective to be fulfilled. 


\section{Atrakcyjność sektorów przemysłu w procesie rozwoju kraju i Mazowsza dawniej i dziś}

\section{STRESZCZENIE}

Niniejsze opracowanie przedstawia próbę odpowiedzi na 4 podstawowe pytania, a mianowicie:

1. Jakie działania zostały wykorzystane $\mathrm{w}$ pierwszym etapie procesu transformacji $\mathrm{w}$ polskim przemyśle w latach 1990-2018 w celu promowania jego rozwoju i czy zmiany w nich są obecnie wymagane?

2. Jakimi kryteriami należy kierować się przy wyborze najatrakcyjniejszych gałęzi przemysłu w celu zapewnienia najbardziej dynamicznego rozwoju przemysłowego kraju i czy kryteria te należy teraz skorygować w sytuacji globalnego kryzysu ekologicznego?

3. Jakie zmiany zaszły w najbardziej obiecujących branżach w procesie transformacji?

4. Jakie branże mogą być najbardziej atrakcyjne dla rozwoju miasta Warszawy i województwa mazowieckiego w przyszłości?

Głównym celem tej pracy jest pokazanie jak przejść od przemysłu, którego konkurencyjność opiera się na taniej sile roboczej, do nowego przemysłu, w którym innowacyjność i rozwój jego innowacyjnych sektorów będzie odgrywał główną i decydującą rolę.

Słowa kluczowe: przemysł, rozwój, proces transformacji w przemyśle, atrakcyjne gałęzie przemysłu dla Warszawy i Mazowsza

Translated by Wojciech Dąbrowski

$\overline{\text { Andrzej Karpiński }}$ - retired associate professor, author of many economic books, long-term secretary of the Forecast Committee of the Polish Academy of Sciences "Polska 2000 Plus".

Andrzej Karpiński - emerytowany profesor nadzwyczajny, autor wielu książek ekonomicznych, wieloletni sekretarz Komitetu Prognoz Polskiej Akademii Nauk „Polska 2000 Plus". 